\title{
鼻アレルギーレーザー治療の長期成績 ーアンケート結果を中心にー
}

\section{中之坊 学、井上 鐵三}

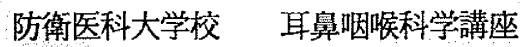

\author{
Long-term Result of Laser Surgery for Allergic Rhinitis \\ Manabu Nakanoboh, Tetsuzo Inouye \\ Department of Otolaryngology, National Defense Medical College.
}

Abstract; Since 1986 we have performed laser surgery to more than 200 patients with allergic rhinitis and obtained good result. However, long-term results remain obscure. Lately we conduct a questionnaire on these cases which received laser surgery more than two years ago. The subjects are 70 cases of the 96 cases (80\%) for which laser surgery was effective excluding 26 cases whose address was unknown because of removal among 118 cases which received laser surgery between March, 1986 and March, 1991. Of the 70 cases, 50 cases (response rate $71 \%$ ) responded to the questionnaire. The effectiveness of the therapy continued over the long period of time (26 months at the shortest, 62 months at the longest, 41.7 months on the average) in 38 (76\%) out of 50 cases. However, recurrence was noted in 12 cases (24\%). Regarding the recurrence, it tended to be seen frequently in the cases which were severe before surgery, but there was no correlation between the recurrence on one hand and the degree of improvement after surgery and age on the other.

（目的）1986年以来、我々は、200例を越える 鼻アレルギ一患者に対しレーザー手術を行い、 有堵な成績をおさめてきたい2)。(図1）しか しながら、良性疾患の性質上、長期にわたり経 過を観察できる症例は少なく、本治療法の長期 成績に関しては不明であった。今回レーザー治 察後 2 年以上経過する症例に対しアンケート調 查を行い、本法の長期成績にについて考察した。
図 1 鼻アレルギーレーザー治療の短期成誉 (街後 1 っ月目)

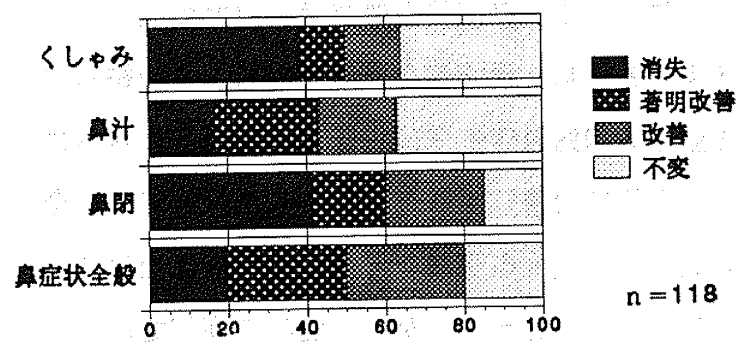




\section{（対象および方法）}

1986.3月〜1991.3月の間にレーザー治寮を行 った鼻アレルギー患者 118例中、レーザ一治療 が有効（症状の消失、著明改善、改善例）であ った96例（80\%）のうち、転居などにより住所 不明であった26例を除く70例に対しアンケート 調查を実施した。当科では術後 $4 \sim 5$ 週目（約 1 力月目）に効果判定を行っているが、アンケ 一トでは、その時点と現在とを比較した鼻症状 の変化について質問した（図2）。すなわち、 患者の自覚症状をもとに、レーザー治療の効果 の持続性について検討した。

図2．アンケート内容（一部）

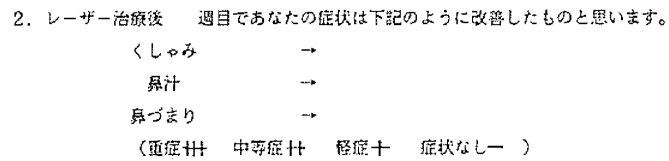

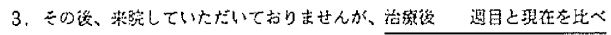

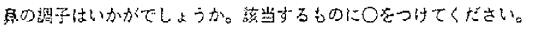

（結果）

アンケート調查を実施した70例のうち回答が 得られたのは50例（回収率71\%）であった。こ れら50例の術後経過期間は、最短で26力月、最 長で62力月、平均42.4力月であった。術後 1 力 月目の鼻症状と現在のそれを比較したアンケー ト結果は図 3 のごとくであった。各鼻症状間に 大差はなく、舅症状全般では、54\%の症例で術 後の改善した状態が 2 年以上にわたり持続して おり、22\%の症例では術後 1 か月目よりさらに 鼻症状は改善していた。これらの症例では、全 例、内服薬・点䁷剂などの併用治療は受けてい なかった。しかしながら、24\%の症例ではアレ
ルギー症状の再発が見られ、再発までの期間は、

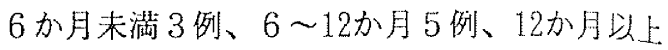
4 例であった。

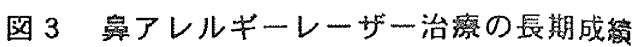
(街後 1 ヶ月目との比整において)

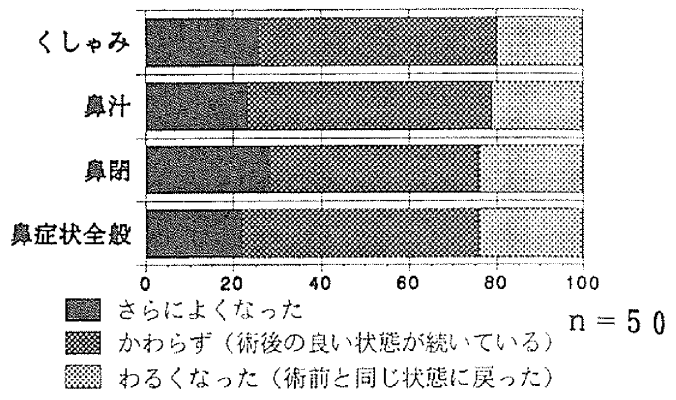

(考察)

当科では、鼻アレルギーのレーザー手街後 4 〜 週目 (約 1 力月目) に效輩判定を行い、そ の時点では $80 \%$ の有効率を得ているが、これは いわば短期成績であり、本法が外科的な局所療 法で原因治療とは異なるために、その長期成績、 言い換えると効果の持続性については筑問が残 るところであった。

今回のアンケート調查では、術後 1 力月目で レーザー治療が有効であった鉦例の $76 \%$ （38例） は最短で26力月、最長で62力月、平均41.7力月 レーザー治族の効壆が持繶しており、内科的治 療を含めその他の治㙩を一切受けることなく経 過していた。また、これら76\%のうち22\%(11 例）は術後 1 力月目よりさらに宜症状は改善し ており、これらの站例では、術後 1 力月日の時

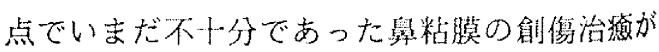
その後完成したものと考えられる。

一方、24\%（12例）の症例では術後1力月目 で改善した䀘症状が再び術前と同じ状態に戻っ ており再発例と考えられた。これら烀発群とり 一ザー治療の効果が持続していた非再発群を比 
較检討してみると、まず性別・年齡別分布（図 4)では、両群間に有意差は見られず（ $\chi^{2}$ 検 定、 $\mathrm{p}<0.05) 、 20 才 以 下 の$ 若年層についてみて も20例中 5 例 (25\%) に再発が見られたが全体 の再発率とほぼ等しく、若年層に特に再発しや すいという傾向はなかった。次に、図5に示す ように、奥田分類による術前の重症度を両群間 で比較してみると、再発群に術前重症例（H が多く見られる傾向があった。また図6に示す ように、術後 1 力月目の改善度を雨群間で比較 してみても有意差はなく（H検定）、再発群の 術後改善の度合いが不良なわけではなかった。 再発群12例のうち 5 例はレーザーによる再手術 を行い、現在経過良好である。

大塚ら ${ }^{31}$ は、通常の下甲介剪刀を用い、鼻閉 を訴える難治性鼻アレルギー患者に舅粘膜広沉 切除術を行い、その遠隔成績をわれわれ同様ア ンケートにより検討した。術後 2 年まで处来で 観察したところ、鼻閉に対しては88\%の有効率 が得られたが、 5 年以上経過した症例のアンケ 一ト結果では、その改善率は約20\%低下し70\% 前後であったと述べている。この結果は今回の われわれの結果と近似しており、術前の重症例 （特にくしゃみ・舅汁）は術後再発の可能性が あり注意を要すると述べている。

図4 アンケート調查群の性別・年令別分布

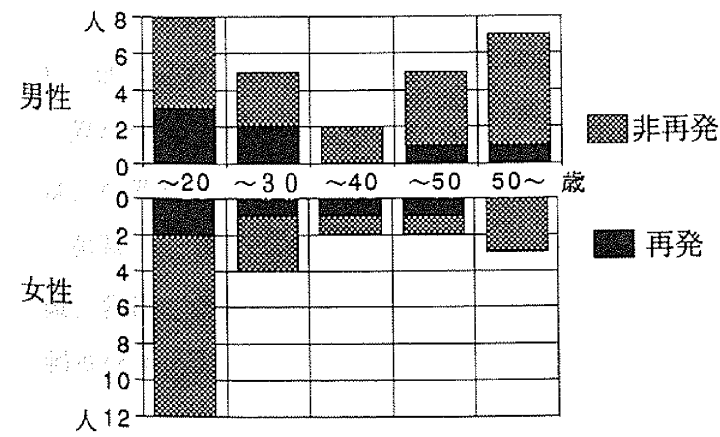

\section{図 5 術前重症度と再発の有無}

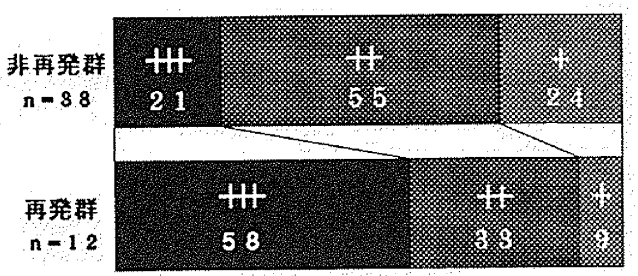

図 6 術後改善度と再発の有無

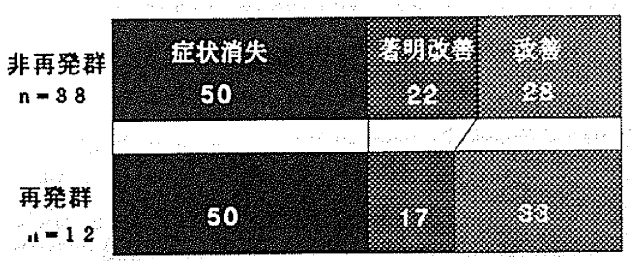

術後長期を経た鼻粘膜病理組織像を両群間で 比較してみると、図7は非再発例の術後42力月 目の $\mathrm{H}-\mathrm{E}$ 弱拡像であるが、粘膜上皮は円柱上 皮が重層化した形態をとるものや扁平上皮化生 したもので、粘膜固有層には浮腫、好酸球の浸 潤、鼻粘膜腺などほとんど見られずコラーゲン 織維のみが見られる瘕痕様組織に置換されてい る。一方、図 8 は再発例の術後51力月目の H一 $\mathrm{E}$ 弱拡像であるが、上皮は多列線毛上皮で多数 の杯細胞と線毛細胞からなり、粘膜固有層には 浮腫と多数の好酸球浸潤および鼻粘膜腺がみら れる典型的なアレルギー鼻粘膜の所見を呈して いる。この症例では、術後18力月目頃よりアレ ルギー症状が再出現した。レーザー治療後の再 生鼻粘膜が再びアレルギー性の変化を起こした ものと考えられる。術後再発の有無を決定する 因子としては、年齢や術後 1 力月目の改善度と の相関がなく、再発群に術前重症例が多いこと を考えると、アレルギー素因の大小を含め個体 差が大きく関与しているものと推察される。 


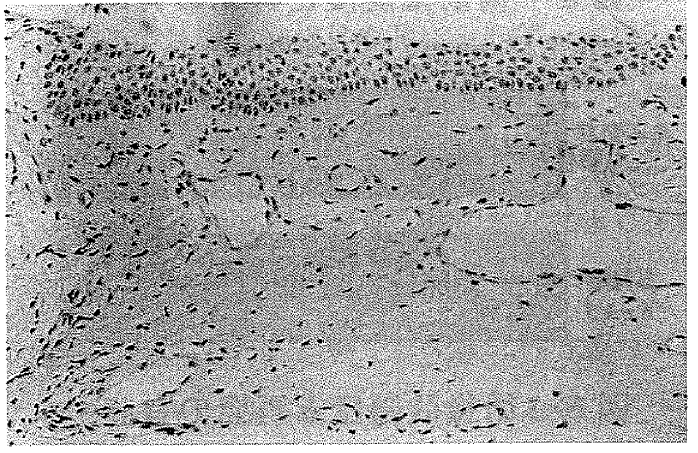

図 7. 非再発例の鼻粘膜像（術後42力月）

$\mathrm{H}-\mathrm{E}$ 弱拡像

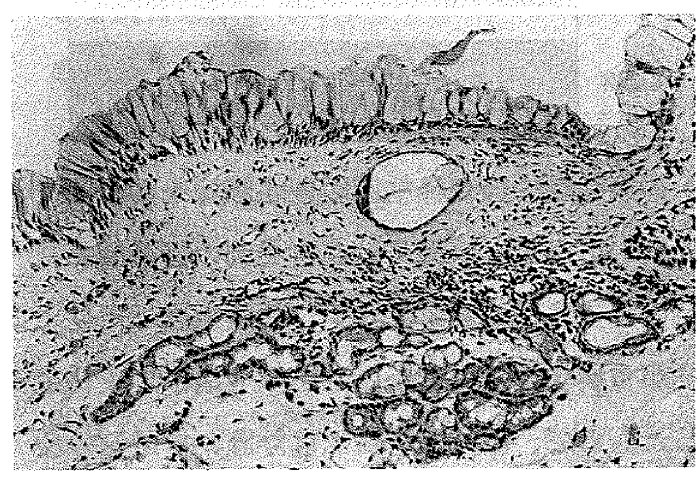

図 8. 再発例の鼻粘膜像 (術後51力月)

$$
\mathrm{H}-\mathrm{E} \text { 弱拡像 }
$$

\section{（結語）}

1. 舅アレルギーレーザー治療の長期成續（特 に効果の持続性）について検討するためにア ンケート調查を行った。

2. 術後短期（1力月目）に勃果のあった症例 の76\%は、その効果が長期（最短で26力月、 最長で 62 力月、平均 41.7 月) にわたり持続 していた。

3.一方で、 $24 \%$ に再発が見られ、再発に関し ては、術前重症例に多く見られる傾向はあっ たが、術後 1 力月目の改善度や年齢との相関 は見られなかった。
参考文献

1. 井上鐵三 他: KTP/532 レーザーの使用経 験. 第11回日本レーザー医学会大会論文集。 697-700, 1990 .

2. 中之坊学：アレルギー性鼻炎、肥厚性鼻炎 とレーザー治療. 日本レーザー医学会誌 13 (3) $37-41,1992$.

3. 大塚博邦 他: 舅粘膜広汎切除術: 遠隔成 續について. 耳䐅頭頸60(2).139-144. 1988. 